\title{
PENATALAKSANAAN PEMERIKSAAN CT-SCAN ABDOMEN DENGAN KONTRAS DENGAN KLINIS TUMOR PADAT OVARIUM DI INSTALASI RADIOLOGI RSUD Dr. Hi. ABDUL MOELOEK PROVINSI LAMPUNG
}

\author{
Yeni Maharisa \\ AKTEK radiodiagnostik dan radioterapi patriot bangsa lampung \\ Email Korespondensi: maharisa_yeni@yahoo.com \\ Disubmit: 22 Januari 2022 Diterima: 24 Januari 2022 Diterbitkan: 01 Februari 2022 \\ DOI: https://doi.org/10.33024/mnj.v5i2.5886
}

\begin{abstract}
MANAGEMENT OF CT-SCAN EXAMINATION ABDOMENTS WITH CONTRAST WITH CLINICAL TUMOR PADAT OVARIUM IN THE RADIOLOGY INSTALLATION OF HOSPITAL Dr. H. ABDUL MOELOEK PROVINCE OF LAMPUNG
\end{abstract}

Introduction: In the pre- survey result obtained from the entire radiological eximination in CT-Scan cases of the abdomen found only $1 \%$ of cases with clinical solid ovarian tumors. During the research activities the authors found 129 patients with contrast CT scan during july to september 2019 and there were 1 (one) patient with clinical ovarian solid tumors in the Radiology Installation of hospital Dr. H. Abdul Moeloek Province of Lampung.

Purpose: The purpose of this study was to determine the preparation of an abdominal CT-Scan examination with clinical solid ovarian tumors using contrast media and to determine the results of CT-Scan images with clinical solid ovarian tumors.

Method: this study uses descriptive qualitative method. A sample of 1 patient was a patient who underwent an abdominal CT scan using contrast media with clinical solid ovarian tumor in the radiology Installation of Hospital Dr. H. Abdul Moeloek Province of lampung. Data is obtained from literature studies, observations, and interviews.

Result:Examination of abdominal CT Scan with contrast must be done by filling out informed consent, laboratory checks, namely checking urea creatinine, which aims to determine kidney function. Then fast for 8 hours so that the patient does not feel nauseous or vomit when the contrast material is inserted into the patient's body, perform a skin test before the contrast CT scan to see if there is a history of allergy or not to the contrast material.

Conclusion:The management of abdominal CT -Scan in contrast to clinical ovarian solid tumorsat the Radiology installation Dr.Hi. abdul moeloek General Hospital in Lampung province is quite effectrive, namely to show abnormalities in the organs to be examined as well as the tissues around them.

Keywords:CT-Scan, Abdomen, Tumor padat ovarium 
INTISARI: PENATALAKSANAN PEMERIKSAAN CT-SCAN ABDOMEN DENGAN KONTRAS DENGAN KLINIS TUMOR PADAT OVARIUM DI INSTALASI RADIOLOGI RSUD Dr. Hi. ABDUL MOELOEK PROVINSI LAMPUNG

Latar Belakang: Pada hasil pre-survey, didapatkan dari keseluruhan pemeriksaan radiologi pada Kasus CT- Scan Abdomen hanya ditemukan 1\% kasus dengan klinis Tumor padat ovarium. Selama melakukan kegiatan penelitian penulis menemukan 129 pasien pemeriksaan CT-Scan Abdomen dengan kontras selama bulan juli s/d september 2019 dan terdapat 1 (satu) orang pasien dengan klinis Tumor padat ovarium di instalasi Radiologi RSUD Dr. H. Abdul Moeloek Provinsi Lampung.

Tujuan: Tujuan dari penelitian ini adalah untuk mengetahui persiapan pemeriksaan CT-Scan abdomen dengan kontras dengan klinis tumor padat ovarium, untuk mengetahui teknik pemeriksaan CT-Scan Abdomen dengan kllinis Tumor padat ovarium menggunakan kontras media dan untuk mengetahui hasil gambaran CT-Scan Abdomen dengan klinis Tumor padat ovarium.

Metode Penelitian: Penelitian ini menggunakan metode Deskriptif Kualitatif. Sampel sebanyak 1 orang pasien yaitu pasien yang melakukan pemeriksaan CTScan Abdomen menggunakan kontras media dengan klinis Tumor padat ovarium di Instalasi Radiologi RSUD Dr.H. Abdul Moeloek provinsi Lampung. Data diperoleh dari studi pustaka, observasi dan wawancara.

Hasil: Pemeriksaan CT Scan abdomen dengan kontras harus dilakukan pemeriksaan mengisi inform consent, cek laboratorium, yaitu cek ureum kreatinin, yang bertujuan untuk mengetahui fungsi ginjal. Kemudian berpuasa selama 8 jam agar pasien tidak mual atau muntah saat pemasukan bahan kontras ke dalam tubuh pasien, melakukan skin tes sebelum pemeriksaan CT Scan kontras untuk melihat adanya riwayat alergi atau tidak terhadap bahan kontras.

Kesimpulan: Penatalaksanaan CT Scan abdomen dengan kontras dengan klinis Tumor padat ovarium di Instalasi Radiologi RSUD Dr. Hi. Abdul Moeloek Provinsi Lampung cukup efektif yaitu untuk memperlihatkan kelainan- kelainan pada organ yang akan di periksa serta jaringan di sekitarnya.

Kata kunci: CT- Scan, Abdomen, Tumor Padat Ovarium

\section{PENDAHULUAN}

Berkembangnya ilmu pengetahuan dan teknologi kedokteran khususnya di bidang radiologi yang berkembang pesat pada saat ini, terutama dalam penggunaan alat-alat penunjang diognosa. Sejak tahun 1972, telah di perkenalkan suatu alat canggih serta menempati tempat teratas dalam dunia kedokteran dalam waktu yang sangat cepat, yaitu alat tomografi yang di kendalikan dengan computer, yang dikenal sebagai computer assited tomography (CAT) atau Computerized tomography (CT) (Sjahriar Rasad, 2005).
Tumor Ovarium adalah massa atau jaringan baru yang bersifat abnormal yang terbentuk pada ovarium dan mempunyai bentuk serta sifat yang berbeda dari sel jaringan aslinya hal ini terjadi di sebabkan karna adanya proliferasi dan diffrensiasi yang abnormal dari sel dari ovarium akibat adanya mutasi gen yang mengatur proliferasi sel tersebut.tumor ovarium dapat bersifat jinak maupunganas(https//hellosehat.co $\mathrm{m})$.

Menurut WHO, kasus tumor ovarium meliputi $30 \%$ dari keganasan yang dijumpai pada organ reproduksi wanita atau sekitar 204 ribu 
pertahun resiko seorang wanita untuk mengalami tumor ovarium selama kehidupannya adalah 1 dalam 75 dan resiko meninggalnya adalah 1 dalam 100. Di dunia sendiri, terdapat 125 ribu wanita yang mengalami tumor ovarium setiap tahunnya.Berdasarkan data Riset Kesehatan dasar(Rikesda, prevelensi tumor di indonesia menunjukan adanya peningkatan dari1.4 per 1000 penduduk pada tahun 2013 menjadi 1,79 per 1000 penduduk pada tahun 2018.

Pada hasil penelitian presurvey, didapatkan dari keseluruhan pemeriksaan radiologi pada CT Scan Abdomen hanyadi temukan 1\% kasus dengan klinistumor padat ovarium. Selama melakukan kegiatan penelitian, penulis menemukan 129 pasien pemeriksaan CT-Scan Abdomen dengan kontras selama bulan juli s/d september 2019 dan terdapat (satu) orang pasien dengan klinis tumor padat ovarium di Instalasi Radiologi RSUD Dr. Hi. Abdul Moeloek provinsi Lampung.

Berdasarkan data tersebut, penulis beranggapan bahwa kasus tumor padat ovarium jarang di jumpai pada pemeriksaan radiologi.oleh karna itu, penulis ingin mengkaji dan menyajikan Lebih lanjut tentang prosedur pemeriksaan CT-Scan Abdomen dengan kontras.

\section{HASIL PENELITIAN DAN PEMBAHASAN}

Pemeriksaan CT Scan Abdomen kontras pada pasien dengan klinis Tumor padat ovarium Hasil : Hepar tak membesar, Densitas normal, tak tampak massa I nodul V.hepatica, V.porta dan ductus hepaticus tak prominent. Vesica fellea : Dinding tak menebal, Tak tampak massa / batu / sludge Pancreas densitas normal, Tak

\section{METODELOGI PENELITIAN}

Jenis Penelitian kualitatif

dengan pendekatan observasi. Populasi yaitu seluruh pasien CTScan Abdomen dengan kontras di Instalasi Radiologi RSUD Dr. H. Abdul Moeloek provinsi lampung pada bulan juli s/d september 2019 sebanyak 1 (satu) orang pasien. Jumlah Sampel yaitu 1 pasien CTScan Abdomen dengan kontras dengan Klinis Tumor padat ovarium, Teknik pengumpulan data yang digunakan yaitu studi pustaka, observasi dan wawancara. Alat ukur wawancara kepada radiographer sebanyak 6 pertanyaan berupa persiapan khusus pada pemeriksaan CT-Scan abdomen kontras, mengapa harus ada hasil lab ureum dan cratinin, berapa lama delay yang digunakan pada pemeriksaan CTScan dan cara radiographer membatasi paparan radiasi yang diterima oleh pasien. wawancara kepada perawat radiologi sebanyak 4 pertanyaan berupa pemeriksaan awal yang dilakukan kepada pasien sebelum tindakan CT-Scan, tindakan yang dilakukan sebelum pemeriksaan CT-Scan, tindakan yang dilakukan setelah pemeriksaan terhadap pasien, berapa banyak cairan kontras media yang digunakan pada pemeriksaan CT-Scan adomen.

tampak massa / klasifikasi Ductus pankreaticus tak prominent. Lien densitas normal. Tak tampak massa Hillus lienalis tak prominent. Ren dextra : Densitas normal, SPC tak melebar Tak tampak massa / batu. Ren Sinistra densitas normal, SPC tak melebar Tak tampak massa / batu. Vesica urinaria : Dinding tak menebal, Tak tampak massa/batu; Kesan : Tumor solid di meseterium left lower quadrant,dd Tumor solid 
adalah massa (solid/padat) atau abnormal dalam tubuh. Gastrointestinal stromal tumor, gastro intestinal tumor adalah tumor langka yang berasal dari sistem pencernaan namun tumor ini berbeda dengan jenis tumor lain yg lebih sering muncul dari kanker saluran pencernaan atau adena carsinoma. Desmoid tomor Ascites minimal, tumor desmoid merupakan bagian dari kelompok yang langka dari proliferasi jaringan fibrosa yang memiliki kecenderungan bersifat agresif lokal namu tidak bermetastase. Tak tampak kelainan di uterus, adnexa, hepar, vesica fellea, pancreas, lien, kedua ren dan vesica urinaria.

\section{PEMBAHASAN}

Persiapan khusus terlebih dahulu dengan berpuasa 8 jam sebelum pemeriksaan, pasien mengisi inform consent, melakukan skin test sebelum dilakukannya pemeriksaan.

Teknik pemeriksaan CT Scan Abdomen dengan kontras ini memerlukan persiapan khusus yaitu dengan berpuasa 8 jam sebelum pemeriksaan, mengisi inform consent, dan melakukan skin tes terlebih dahulu, persiapan pasien CT Scan abdomen ini dengan posisi objek supine diatas meja pemeriksaan dan mengikuti instruksi untuk tarik nafas dan dikeluarkan kemudian tahan nafas sebentar yang diberi aba- aba dari pesawat CT Scan 128 slice. Pasien yang di periksa saat ini melakukan kontras oral. Tahap awal pemasukan bahan kontras ke dalam rectal melalui kateter yang bertujuan sebagai marker rektal untuk pembeda antara abdomen dengan dinding sigmoid di masukan sebanyak $500 \mathrm{ml}$ air- $8 \mathrm{cc}$ obat perbandingan 1;3 kemudian lakukan scaning, tahap akhir adalah pasang alat injector syringe yang di dalamnya sudah di isi 1 air dan 1 bahan kontras, dengan volume kontras media $1 \mathrm{ml} / \mathrm{BB}$ pasien, jadi $60 \mathrm{~kg}$ BB pasien/ $1 \mathrm{ml}$ bahan kontras dengan waktu penyuntikan 2-3 cc/detik lakukan scan kembali, pemeriksaan CT Scan abdomen dengan kontras ini di lakukan dengan dua proses yaitu sebelum pemasukan bahan kontras atau pre kontras dan pemeriksaan sesudah pemasukan bahan kontras, CT Scan abdomen pre kontras yang di lakukan bertujuan untuk melihat hasil persiapan khusus yang di lakukan, atau pada pemeriksaan pre kontras adanya kelainan yang sesuai dengan klinis sudah terlihat atau belum, jika belum terlihat maka dilakukanya pemeriksaan ct scan dengan pemasukan bahan kontras yang di lakukannya pemeriksaan CT Scan dengan pemasukan bhan kontras melalui rektal yang bertujuan sebagai marker rektum atau pembeda antara dinding Abdomen dan colon sigmoid. Kemudian pemasukan bahan kontras yang di lakukan dengan penyuntikan melalui intra vena dengan bantuan venflon,kemudian atur untuk scanning kembali.Setelah itu lakukan post contras.

Pemeriksaan

CT-Scan Abdomen dengan kontras dilakukan dengan 2 proses, yaitu sebelum pemasukan bahan kontras (prekontras) dan pemeriksaan sesudah kontras (post-Kontras). Setelah proses scanning selesai pilih data dari pasien lalu dilakukan pemilihan data pre kontras dengan cara di klik, lalu akan tampil pada layar monitor work station tampilan potongan axial, sagital, dan coronal, kemudian pilih view coronal lalu klik, maka akan tampil gambaran/garis potongan yang dapat diatur oleh radiografer dalam menentukan potongan axial, dengan batas atas diafragma sampai batas bawah, dibawah syhmphisis pubis dan 
pemilihan slice/potongan sebanyak 48 slice termasuk topogram lalu klik outview maka akan tampil gambaran potongan axial pre kontras dalam 2 sheet film dengan ukuran $4 \times 6$, lalu gambaran disesuaikan agar tidak terpotong setelah sesuai, maka lakukan printing sehingga akan tercetak ke printer.

\section{KESIMPULAN}

Pemeriksaan CT-Scan abdomen dengan kontras harus dilakukan pemeriksaan mengisi inform consent, cek laboratorium, yaitu cek ureum kreatinin, yang bertujuan untuk mengetahui fungsi ginjal. Kemudian berpuasa selama 8 jam agar pasien tidak mual atau muntah saat pemasukan bahan kontras ke dalam tubuh pasien, melakukan skin tes sebelum pemeriksaan CT-Scan kontras untuk melihat adanya riwayat alergi atau tidak terhadap bahan kontras.

Benda- benda logam di daerah yang akan di periksa, posisikan pasien Teknik pemeriksaan CT Scan Abdomen dengan kontras di instalasi Radiologi RSUD. Dr.Hi. Abdul Moeloek Provinsi Lampung sudah sesuai dengan prosedur tetap yang ada di rumah sakit tersebut, adapun prosedurnya yaitu: sebelum dilakukanya pemeriksaan CT Scan abdomen pasien diminta untuk meninggalkan supine di atas meja pemeriksaan, atur posisi feet first, kedua tangan di atas kepala dimana posisi pasien daerah abdomen bisa tercover dalam lapangan penyinaran. Kemudian lakukan pemasangan kateter via anus dan masukan cairan kontras, Kemudian lakukan scaning topogram yang akan menampilkan gambaran abdomen posisi AP di layar monitor, Ketika proses scanning berlangsung pasien di instruksikan untuk tidak bergerak hingga pemeriksaan selesai. Kemudian. kemudian lakukan scaning kedua dengan memasang alat injektor untuk menyuntikan bahan kontras media ke dalam intravena $60 \mathrm{ml}$ diatur flowe rate 2 $3 \mathrm{cc} /$ detik, lakukan scaning kembali, setelah selesai pasien di rapihkan dan di instruksikan untuk meninggalkan ruangan, kemudian lakukan reconstruksi hasil gambaran CT-Scan dan di pilih gambar CT-Scan yang akan di print.

Hasil dari CT-Scan abdomen kontras berdasarkan expertise dokter di dapatkan bahwa adanya Tumor solid di meseterium left lower quadrant, dd: malignant limph node, gastrointestinal stromal tumor, desmoid tumor Ascites minimal yang di dapat pada potongan axial.

\section{DAFTAR PUSTAKA}

Ballinger, Philip W, Eugene D. Frank. (2003). Merrill's Atlas of Radiographic Positionings and Radiologic Procedures Volume 3, Edition St. Louis Missouri, USA

BAPETEN. (2013). Peraturan Kepala Badan Pengawas Tenaga Nuklir (BAPETEN) Nomor 4Tahun 2013. BAPETEN : Jakarta.

Bontrager, (2001). Text Boox of Radiografhic Positioning and Radiografic Position andRelated Anatomy. Mosby : St. Louis

Kirnantoro, (2017). Anatomi Fisiologi untuk mahasiswa Keperawatan. EGC : Jakarta.

Moeller, B. Torsten. (2007). Pocket Atlas of Sectional Anatomy, Computed Tomografy and MagneticResonance Imaging Volume II. EGC : Jakarta.

Rasad, S. (2005). Radiologi Diagnostik Edisi 2th Edition. Balai Penerbit FKUI : Jakarta. 
Pearce, C. Evelyn. (2011). Anatomi dan fisiologi untuk paramedis. PT Gramedia : Jakarta

Sayuti, T. (2017). Patologi Untuk Mahasiswa Keperawatan EGC : Jakarta.

Wijojongko, S. dkk. (2017). Protokol Radiologi CT Scan dan MRI. Inti Medika Pustaka : Magelang.

Yanyan, B. (2016). Patologi pada abdomen(http: / /www.slide share.net/nurluciana3/pat ologi-urinaria) diakses pada tanggal 3 April 202015.00 WIB

www.alodokter.com. Pengertian Tumor Jinak Ovarium (http: / /www.alodokter.co $\mathrm{m} /$ berbagai-jenis-tumor jinak-berdasarkan letaknya) diakses pada tanggal 04 April 2020 pkl. 12.35 WIB

Hellosehat.com. Penyebab Tumor Padat Ovarium. (https://hellosehat.com/ke sehatan/penyakit/tumor/ ) diakses pada tanggal 04 April 2020 pkl 12. 45 WIB

www.alodokter.com. Penyebab Tumor ganas Ovarium. (https://blog.kitabisa.com /tumor-ganas-ovariumpenyebab-dan-gejalanya) diakses pada tanggal 04 April 2020 pkl 13,00 WIB

www.detiklife.com. Pengertian Tumor Ovarium. (https://hellosehat.com/ke sehatan/penyakit/tumor) diakses pada tanggal 04 April 2020 pkl 13.30 WIB

Harjumbudiman.wordpress.com. Prinsip Kerja CT-Scan. https: / /harjumbudiman.wo rdpress.com/prinsip-kerjact-scanner. Diakses pada tanggal 05 April 2020 pkl 12.35 WIB

Puji, E. (2011). Sejarah perkembangan CT-Scan. (http://ekopujisetiyantosci ence.blogspot.com/2011/0 2/generasi-CT- Scan.html) diakses pada tanggal 02 april 12.30 WIB

Poltekkes Depkes, 2015. Draft Seminar tentang Teknik pemasukan Bahan Kontras. http:// teknik-pemasukanbahan-kontras.html. diakases pada tanggal 05 April pkl 12.40 WIB 